\title{
Hvor prekære vilkår har atypisk ansatte i det offentlige?
}

\section{Steen Scheuer}

I denne artikel undersøges det, om det kan dokumenteres, at atypisk ansatte også har større risiko for prekære vilkår i deres ansættelse i den offentlige sektor. Fire aspekter af vilkår i arbejdet for atypisk ansatte - sammenlignet med normalbeskæftigede - i den offentlige sektor vil blive analyseret. Hensigten er at bedømme, hvorvidt de atypisk ansatte (ud over denne særlige status) har færre goder eller rettigheder, altså en form for underskud i rettigheder. Fire områder af vilkår er undersøgt: Muligheder for jobudvikling, psykisk belastning, juridiske rettigheder i ansættelsesforholdet samt økonomiske forhold.

For at opnå en generel og dækkende dokumentation, baseres undersøgelsen metodologisk på en større repræsentativ survey blandt offentligt ansatte. Undersøgelsen har en opnåelse på 1.303 respondenter, og den blev gennemført i september-oktober 2016.

Analysen viser, at på tre af de fire udvalgte områder var de negative forskelle (de manglende goder) for atypisk ansatte evidente. Mulighederne for jobudvikling, juridiske rettigheder $\mathrm{i}$ ansættelsesforholdet samt økonomiske forhold er klart ringere for atypisk ansatte. Kun når det gælder psykisk belastning, kan der ikke ses signifikante forskelle, hverken positive eller negative.

Da atypisk ansættelse omfatter mere end hver fjerde offentligt ansatte (29\%), omfatter de viste forskelle en meget stor gruppe af offentligt ansatte inden for en række sektorer og faggrupper.

Nøgleord: Atypiske ansættelser, prekære arbejdsvilkår, offentlig sektor, midlertidige ansættelser, deltid

\section{Indledning}

Termer som atypisk ansættelse, prekære ansættelsesforhold og prekariatet har fået en større brug og opmærksomhed i de seneste 10-15 år. Selv om fænomener som midlertidig ansættelse, projektansættelse og deltidsansættelse bestemt ikke er nye, er der hermed kommet et øget fokus på denne eller disse grupper. Hvor "atypisk ansættelse" er en forholdsvis neutral betegnelse, er en prekær ansættelse det bestemt ikke, og selv om selve udtrykket "prekariat" nok virker overdrevet i den danske velfærdsstat, er det blevet klart i debatten, ude i verden såvel som herhjemme, at udtrykket i sin praktiske anvendelse betegner relativ prækaritet og ikke absolut. Det er altså, når forskellene i de relative vilkår mellem beskæftigelse under normale forhold ("normalbeskæftigede") og under atypiske ditto bliver tilstrækkeligt store, at man kan tale om prækaritet (jf. bl.a. Andersen \& Karkov, 2011; Eichhorst \& Tobsch, 2013; Gleerup et al., 2018; ILO, 2016; Keune, 2013; Larsen, 2011; Larsen \& 
Mailand, 2018; Standing, 2011; Svalund, 2013; Thörnquist \& Engstrand, 2011). Definitorisk anses normalbeskæftigelse som (a) en ansættelse på fuld tid efter arbejdsmarkedets aktuelle standarder, dvs. en arbejdsuge på omkring 37 timer eller mere og (b) en ansættelse uden en fastsat udløbsdato. Dette kaldes i litteraturen 'the standard employment relationship', dvs. standardansættelsesforholdet. Ved atypiske ansættelsesformer er den ene eller den anden af disse betingelser ikke opfyldt, eventuelt begge, jf. nedenfor.

Det 20. århundredes altdominerende form for beskæftigelse på arbejdsmarkedet i den industrialiserede del af verden har netop været normalbeskæftigelse. Indtil begyndelsen af århundredet var langt de fleste lønmodtagere ansat mere eller mindre på daglejervilkår, og årsagen til, at den faste fuldtidsbeskæftigelse vandt frem, var primært to ting:

a. Lønmodtagernes behov for beskyttelse imod markedets kortsigtede fluktuationer, dvs. deres risikoaversitet, og dertil fagbevægelsens tiltagende forhandlingsstyrke, men også

b. Arbejdsgivernes behov for en loyal arbejdsstyrke, som betragter ansættelsen som en langsigtet investering, og ikke ud fra et opportunistisk dag til dag-perspektiv: De ansatte skulle også have en interesse i virksomhedens overlevelse på længere sigt, og virksomhederne kan få et incitament til at investere i medarbejderens kompetenceudvikling, da disse forventes at forblive i virksomheden på længere sigt. (jf. Marsden, 2004; Rubery et al., 2018)

Der bliver hermed tale om, at de ansatte beskyttes imod de værste sider af det kapitalistiske varemarkeds kortsigtede fluktuationer, en beskyttelse der kan betegnes som 'dekommodificering' af markedet for arbejdskraft (Rubery et al., 2018). Med den øgede udbre- delse af atypiske ansættelsesformer i det 21 . århundrede synes udviklingen at gå i den modsatte retning: $\mathrm{Nu}$ er markedseksponeringen igen stigende, og den er fokuseret på bestemte grupper, defineret kontraktuelt af deres ansættelsesform. Denne 'rekommodificering' rejser spørgsmålet, om hvor stor en forskel der egentlig er mellem de normal- og de atypisk ansatte, og om atypisk ansatte bliver udsat for markant ringere vilkår ud over selve det rent kontraktmæssige, altså at risikoen for prækaritet er markant forøget.

At fremhæve bestemte gruppers øgede risiko for prækaritet - eller den øgede prækaritet på arbejdsmarkedet - udtrykker en kritik af arbejdsmarkedets strukturelle udvikling. Der kan enten være tale om, at den relative andel af atypisk ansatte stiger, og at dette undergraver eller mindsker dækningsområderne for de lov- og overenskomstmæssige rettigheder og vilkår hos fastansatte, eller der kan være tale om, at vilkårene for de prekært ansatte relativt set forværres, hvilket også udgør en trussel i forhold til flertallets vilkår, fordi de atypisk ansatte hermed udgør et for arbejdsgiverne attraktivt alternativ til normalbeskæftigede, der har flere rettigheder, som kan koste.

I denne artikel fokuseres der særligt på prekære vilkår i den offentlige sektor, dvs. ubegrundede uligheder mellem normalbeskæftigede og atypisk ansatte her. Den offentlige sektor har i nogen grad været overset i debatten om atypiske ansættelser (Crouch, 2015; Pfeifer, 2011, jf. næste afsnit), og den burde på grund af den politiske regulering af ansættelsesforholdene i højere grad end den private sektor være en form for garant for ordnede vilkår på arbejdsmarkedet, også fordi det offentlige arbejdsmarked er helt gennemgående aftalereguleret (overenskomstdækningen er tæt på 100\%, jf. DA, 2014, s. 186), og pga. den større grad af offentlighed omkring vilkår i det offentlige. Spørgsmålet er imidlertid, om dette holder stik. Atypiske 
ansættelser (deltids- og tidsbegrænsede ansættelser) er faktisk temmelig udbredte i den offentlige sektor (jf. afsnit 4), og det er derfor et interessant spørgsmål, om de vilkår, de offentlige arbejdsgivere tilbyder de atypisk ansatte, kan kaldes prekære, set i forhold til de fastansatte offentligt ansattes vilkår.

Definitionsmæssigt skal det præciseres, at i denne artikel er selve det at være atypisk ansat ikke i sig selv udtryk for prækaritet. Temaet er derimod, i hvilket grad atypisk ansættelse øger risikoen for manglende rettigheder elle ansættelsesmæssigt underskud (de såkaldte "work deficits", jf. ILO 2016). Sådanne mangler må ses som ubegrundede, da enten lovgivning eller overenskomster på de forskellige områder forudsætter ligebehandling mellem normal- og atypisk beskæftigede.

Atypisk ansættelse defineres herefter som en ansættelse, der er karakteriseret ved de følgende to kriterier, eller evt. begge dele: Ansættelsen indeholder enten kortere ugentlig arbejdstid end den på arbejdsmarkedet normale eller den er karakteriseret ved at kontrakten er tids- eller opgavebegrænset (jf. Kalleberg, 2011). Hos Kalleberg er prekært arbejde ikke begrænset til atypisk ansatte, idet fx lavtlønsjob med hyppige fyringer også bliver inddraget. I denne artikel ses dog mere specifikt på, i hvilken grad atypiske ansættelsesformer kan føre til prækaritet. Den hypotese, der skal forfølges i denne artikel, er, at "non-standard employment is not necessarily precarious, but much of precarious employment is non-standard" (Keune \& Pedaci, 2019, s. 5).

Prekære vilkår defineres herefter som vilkår, der afviger signifikant og negativt fra normalansattes vilkår, og hvis dette kan findes på en større andel af de undersøgte vilkår i jobbet, kan man tale om egentlig prækaritet for de atypisk ansatte. Prækaritet forekom- mer i så fald i denne undersøgelse hos en ægte delmængde af de atypisk ansatte.

Hvor kommer udtrykket "atypisk ansættelse" egentlig fra? Det oprindelige udtryk var "atypiske kontrakter," og baggrunden for disse var, at man tidligere havde (og i nogen grad stadig har) en meget stærk ansættelsesbeskyttelse især i en række sydeuropæiske lande, og dette skabte en stivhed på de europæiske arbejdsmarkeder, hvor virksomheder var tøvende over for at ansætte, fordi opsigelsesreglerne var så stramme. Man talte dengang om "eurosklerose", medførende høj ledighed, især blandt unge og nyuddannede. Som et svar herpå indførte man i 1984 i Spanien og Italien såkaldte "atypiske kontrakter", dvs. tidsbegrænsede ansættelser, som kunne anvendes i alle sammenhænge (EP, 2016, s. 28). Denne kontraktmulighed mindskede faktisk ungdomsledigheden, men skabte til gengæld et mere dualt arbejdsmarked, hvor de midlertidigt beskæftigede havde (og har) lav ansættelsessikkerhed på bare lidt længere sigt, og hvor arbejdsgiverne ikke var synderligt villige til at lade de midlertidigt ansatte opnå fast beskæftigelse (Doeringer \& Piore, 1971).

Undertiden skelnes der mellem, om den atypiske ansættelse er selvvalgt eller ufrivillig. I forbindelse med deltid viser forskningen, at omkring halvdelen af de deltidsansatte selv har valgt deltid, mens kun omkring hver femte selv har valgt en midlertidig ansættelse. Man ved endvidere, at selvvalgt kontraktstatus medfører større tilfredshed med jobbet og mulighederne (fx Kauhanen \& Nätti, 2015; Manyika et al., 2016). I denne artikels sammenhæng er graden af selvvalg ikke centralt, da man udmærket kan være udsat for ringere rettigheder fx som deltidsansat, selv om det er ens eget valg. De manglende rettigheder eller ringere vilkår gælder uanset. 


\section{Prækaritetseffekter \\ i den offentlige sektor \\ - nogle overvejelser}

Regulering af arbejdsforhold og rettigheder i den offentlige sektor er på mange måde præget af en mere omfattende og for medarbejderne mere sikker position end i den private sektor, bl.a. fordi det er opfattelsen, at:

- Stort set alle offentligt ansatte er dækket af en kollektiv overenskomst, en tjenestemandsaftale eller en anden form for aftale mellem parterne (jf. fx DA, 2014, s. 186).

- Langt de fleste offentligt ansatte er dækket af enten funktionærloven eller tjenestemandsloven

- Hermed har alle offentligt ansatte i princippet ret til at vælge tillidsrepræsentant (TR), og TR-dækningen er da også betydeligt højere i den offentlige end i den private sektor (Larsen et al., 2010, s. 243)

- Offentlighed i forvaltningen og mulighed for indsigt i fx lønforhold giver de offentlige ansattes organisationer større indflydelse på selve løndannelsen.

- De offentlige arbejdsgivere er i princippet nødt til at optræde mere socialt ansvarligt i forbindelse med $\mathrm{fx}$ afskedigelser og sikring af overenskomstsikrede løn- og arbejdsvilkår.

Derfor kunne man umiddelbart forvente, at offentligt ansatte har bedre sikkerhed, og at dette også gælder de medarbejdere, der er ansat på atypiske vilkår, fx som midlertidigt eller deltidsansatte, ligesom man måtte forvente, at der i det hele taget er færre atypisk ansatte, især færre midlertidigt ansatte, i den offentlige sektor.

Spørgsmålet er imidlertid, om dette er en rigtig antagelse. Man kan nemlig anlægge en anden synsvinkel, hvor man anskuer offentligt ansatte som mere beskyttede inden for "ikke-markedssektoren", hvor løn og arbejdsvilkår ikke styres af markedskræfterne, men af staten som arbejdsgiver, og hvor fagforeningerne kan tiltvinge sig (forhandle sig til) større beskyttelse end i det private. Den større beskyttelse af de ansatte får imidlertid en pris, idet beskyttelsen øger arbejdsgivers behov for en fleksibel arbejdskraft, hvilket indebærer øget brug af atypiske ansættelsesformer med ringere vilkår for de "ubeskyttede". Dette har de fastansatte ikke noget imod, da de atypiske fungerer som en fleksibilitets-buffer, som beskytter de fastansatte imod ændringer og nedskæringer i den offentlige sektor (Crouch, 2015; Pfeifer, 2011). Prisen for beskyttelsen af offentligt ansatte betales således af dem, der ikke har opnået fast fuldtidsbeskæftigelse. Dette er parallelt med det forhold, at i Europa har lande med høj ansættelsesbeskyttelse (bl.a. Belgien, Frankrig, Italien og Spanien) også en langt højere andel atypisk ansatte, end der fx er i Danmark og Storbritannien.

Denne lidt mere fagforeningsuvenlige udlægning indebærer, at hovedhypotesen for artiklen er, at der kan påvises prækaritetseffekter, dvs. at de atypisk ansatte faktisk vil være udsat for manglende rettigheder og større usikkerhed (prækaritet) som følge af deres ansættelsesforhold. Pointerne fra den internationale forskningslitteratur er nemlig, sammenfattende, at forholdene for atypisk ansatte er mere markedseksponerede og risikobetonede, og at fagbevægelsens kamp for at 'normalisere' arbejdsforholdene for de atypisk ansatte er en kamp op ad bakke, også ud fra studier inden for brancher i den offentlige sektor (Keune \& Pedaci. 2019, Rubery et al., 2018).

\section{Undersøgelsens design og analysemetode}

For at opnå en generel og dækkende dokumentation, baseres undersøgelsen metodolo- 
gisk på en større repræsentativ survey. Data til denne undersøgelse blev oprindeligt indsamlet i forbindelse med et større projekt, hvis formål var at dokumentere arbejdsmarkedsvilkårene for atypisk beskæftigede i Danmark på hele arbejdsmarkedet. Undersøgelsen var finansieret af LO (jf. Scheuer, 2017). Undersøgelsens univers blev således defineret som en simpel randomiseret stikprøve blandt alle lønmodtagere i alderen fra 18 år og opefter. I denne artikel er dog kun medtaget respondenter ansat i den offentlige sektor.

Selve dataindsamlingen er foretaget af konsulent- og markedsanalysefirmaet Epinion A/S. Undersøgelsen er foretaget som en webbaseret spørgeskemaundersøgelse (CAWI), hvor deltagerne er medlemmer af Epinions online paneler. Dataindsamlingen til denne undersøgelse er foregået i perioden 23. september til 16. oktober 2016 i Epinions Danmarkspanel, og i alt har et udsnit på 7.554 repræsentativt udvalgte danskere tilgået undersøgelsen. Panelet indeholder ifølge Epinion 245.000 panelister med en månedlig tilgang på 7.500, og det tilstræbes, at det udgør et repræsentativt udsnit af befolkningen. Målgruppen for den oprindelige undersøgelse var ansatte lønmodtagere (både normalbeskæftigede og deltids- og midlertidigt ansatte) samt også tilkaldevikarer i den private og offentlige sektor. Personer, som ikke aktuelt er tilknyttet arbejdsmarkedet, fordi de enten er syge, har orlov, er under uddannelse eller er kontanthjælps- eller dagpengemodtagere, har kunnet deltage $\mathrm{i}$ undersøgelsen, hvis de tidligere har været tilknyttet arbejdsmarkedet. Disse er blevet bedt om at svare ud fra forholdene i deres seneste job. Undersøgelsen foregik på dansk, hvilket udelukker ikke-dansktalende arbejdstagere. Undersøgelsen omfatter således både normal- og atypisk beskæftigede for at mulig- gøre komparative analyser af fordelingen af forskellige typer af vilkår, rettigheder og muligheder på arbejdsmarkedet.

Den gennemsnitlige svartid på undersøgelsen er omkring 11 minutter. Taget i betragtning af undersøgelsens længde er et frafald på $12 \%$ blandt dem, der har påbegyndt undersøgelsen, relativt lavt. Der blev gennemført 4.099 interview i den private og offentlige sektor, heraf var de 3.544 fuldt brugbare til analyserne. I alle tabellerne undtagen tabel 1 er dog som nævnt kun medtaget respondenter, der er ansat $i$ den offentlige sektor, i alt 1.303 personer.

Et par ord om undersøgelsens reliabilitet: Når det gælder vilkår på arbejdsmarkedet, hører man undertiden det argument, at en del lønmodtagere ikke kender ret meget til - måske ikke interesserer sig for - deres rettigheder (deres vilkår, fx arbejdstid, kender de jo nok). Hvor mange er fx klar over, om de har en arbejdsmarkedspension? Om dette kan man anføre, dels at netop pensionsopsparing nok interesserer de fleste og også er noget, man modtager information om, og dels at det for nogle af svarenes vedkommende er muligt at konferere fordelingen med mere objektive, fx registerbaserede opgørelser. Når det eksempelvis gælder arbejdsmarkedspension (inkl. tjenestemandspension), dvs. opsparinger med arbejdsgiverbidrag, viser registerbaserede opgørelser, at lige knap 90\% af alle lønmodtagere har en sådan, mens $87 \%$ af samtlige lønmodtagere (privat og offentligt ansatte) har en arbejdsmarkedspension $\mathrm{i}$ den survey, der anvendes her. Dette viser, at den subjektive svarfordeling i denne survey rammer præcist i forhold til andre, mere objektive måletyper (Finansministeriet, 2017; Scheuer, 2017). Der er derfor god grund til at fæste lid til, at analyseresultaterne er repræsentative for undersøgelsens univers, og at svarfordelingerne står til troende. 


\section{Strukturen af atypisk ansættelse: Hvilke grupper i det offentlige er især atypisk ansat?}

Indledningsvis må det konstateres, at andelen af atypiske ansættelser i det offentlige er noget højere end i det private: Hvor $22 \%$ af privatansatte lønmodtagere er atypisk ansat, gælder dette for hele 29\% i det offentlige, jf. tabel 1. Denne forskel er klart signifikant. Man kan derfor ikke sige, at det offentlige går foran, når det gælder at sikre ansættelsesformerne, næsten tværtimod. Normalt opfattes offentlig ansættelse som mere sikker end privatansættelse (ansættelsesbeskyttelsen er bedre), men det offentlige holder til gengæld flere på 'den atypiske pinebænk', så at sige. Udtrykt i sandsynlighed er odds for at være atypisk ansat i det offentlige - overordnet set - næsten en halv gang større (odds ratio $=1,4$ ) end i det private. Dette synes at udtrykke, at det offentlige har færre anfægtelser over for disse mindre sikre ansættelsesforhold end virksomhederne i den private sektor. I andre sammenhænge - fx hvad angår lønudviklingen - fremhæves det ofte, at lønudviklingen i det offentlige skal afspejle udviklingen i den private sektor, men når det gælder ansættelsesformerne, må det offentlige tilsyneladende gerne halte et godt stykke bagefter. Tabellen viser endvidere, at det især er i brugen af midlertidige ansættelser, at den offentlige sektor skiller sig negativt ud: I den offentlige sektor er næsten hver femte midlertidigt ansat (18\%), mens det i den private sektor er 14\%. Det offentlige burde nok være bedre til at matche mønstret i den private sektor?

Tabel 1.

Andel atypisk ansatte i privat og offentlig sektor, opdelt på temporært og deltidsansatte. Procent 2016.

\begin{tabular}{lllll} 
Sektor & Temporært ansat & Deltidsansat & $\begin{array}{l}\text { Totalt atypisk } \\
\text { ansatte }\end{array}$ & N \\
\hline Privat sektor & 14 & 20 & 22 & 2.242 \\
\hline Offentlig sektor & 18 & 21 & 29 & 1.302 \\
\hline Total & 15 & 20 & 25 & 3.544 \\
\hline
\end{tabular}

Note: De to kategorier temporoer og deltid summer til mere end totalen, da nogle både er temporaert og deltidsansat.

Kilde: Undersøgelse af ansaettelsesformer, september-oktober 2016.

Ikke alle faggrupper har dog den samme risiko for atypisk ansættelse. Bl.a. har nogle af de akademiske faglige organisationer været meget optaget af atypiske ansættelser og af prekære ansættelsesvilkår, og også i forskningen har dette fokus været fremhævet. Der har også været fokus på andre grupper, fx butiks- og hotelansatte (Ilsøe, 2016), men i det offentlige også fx pleje- og rengøringsområdet samt undervisning. En profil på, hvilke grupper der især er atypisk ansat i det offentlige, kan fås ved at se på, i hvilke 
fagforbund de udgør en relativt større andel af medlemmerne. Dermed får man en nogenlunde repræsentativ opgørelse, da den faglige organisationsgrad netop i den offentlige sektor er meget høj (91\% af de offentligt ansatte i denne repræsentative undersøgelse er medlemmer af en fagforening). Tabel 2 viser andelen af medlemmerne i større fagforbund (forbund med 25 svarpersoner eller flere i datasættet, $n>24$ ), der er atypisk ansat.

Tabel 2.

Andel atypisk ansatte opdelt efter medlemskab af fagforbund i den offentlige sektor.

Kun forbund med mindst 25 i datasættet $(\mathrm{N}>24)$. Procent 2016.

\begin{tabular}{lll} 
Fagforbund & Andel atypisk ansatte & N \\
\hline BUPL & 28 & 50 \\
\hline DJøF & 24 & 50 \\
\hline Lærerforeningen & 21 & 39 \\
\hline DM Magisterforeningen & 53 & 34 \\
\hline Sygeplejerådet & 35 & 52 \\
\hline 3F & 22 & 79 \\
\hline FOA & 30 & 201 \\
\hline HK & 22 & 249 \\
\hline Kristelig Fagforening & 23 & 39 \\
\hline Øvrige mindre fagforbund & 30 & 276 \\
\hline Ikke medlem af fagforbund & 46 & 121 \\
\hline Totalt i den offentlige sektor & 29 & 1.302 \\
\hline
\end{tabular}

Kilde: Undersøgelse af ansoettelsesformer, september-oktober 2016.

Tabellen viser, at det især er fagforbund som Magisterforeningen og Sygeplejerådet, hvor medlemmerne i høj grad er atypisk ansat, nemlig med hhv. 53 og 35\%, dvs. over gennemsnittet på $29 \%$. Desuden er næsten halvdelen (46\%) af de uorganiserede i langt højere grad atypisk ansat. Desuden ligger FOA med 30\% næsten på gennemsnittet, stort set modsvarende hele den offentlige sektor. Det samme gælder de øvrige mindre fagforbund. Det er høje tal, at tre ud af ti eller mere ikke er normalbeskæftiget. Det er 
nok ikke så sært, at dele af diskussion om atypiske ansættelser ofte fokuserer på magisterområdet (jf. fx Gleerup et al., 2018), selv om udbredelsen går langt ud over dette specialiserede område.

\section{Vilkår i offentlig ansættelse - de undersøgte temaer}

Fokus i denne artikel er derfor, om det atypiske ansættelsesforhold har videregående effekter i form af mere stress, dårligere økonomi, færre rettigheder på arbejdspladsen osv. ifølge dansk lov og også EU-retten må virksomhederne ikke diskriminere imod atypisk ansatte, disse skal have de samme rettigheder som de normalbeskæftigede. Men der ses ikke kun på formelt-juridiske forhold, men også på forhold, der mere generelt anses for centrale $\mathrm{i}$ et ansættelsesforhold $\mathrm{i}$ dag, $\mathrm{fx}$ retten til at udvikle sig i jobbet.

For at belyse de ovenstående problemstillinger skal de følgende mere specifikke indikatorer på prækaritet undersøges i denne artikel:

\section{A. Mulighed for udvikling i arbejdet og for at anvende sine kvalifikationer \\ B. Psykisk belastning - stress og manglende arbejdsliv/familieliv-balance \\ C. Juridiske rettigheder: Ret til løn under sygdom m.m. og til den sjette ferieuge \\ D. Økonomiske forhold: Forudsigelig økonomi og arbejdsmarkedspension}

I litteraturen om atypiske ansættelser har indikatorer som disse tidligere været anvendt internationalt til at påvise ubegrundede uligheder mellem normalbeskæftigede og atypisk ansatte (fx Gallie 2008; Kalleberg, 2009; Kauhanen \& Nätti, 2015), og i enkelte tidligere danske undersøgelser (Navrbjerg \& Larsen, 2011; Scheuer, 2011).
Vilkår A. Mulighed for udvikling $i$ arbejdet og for at anvende sine kvalifikationer

Mulighed for at udvikle sig i jobbet og videreudvikle sine evner og kvalifikationer er undersøgt ved hjælp af tre spørgsmål i surveyen. Individuelle medarbejdersamtaler - ofte kaldet medarbejderudviklingssamtaler (MUS) - med det formål at kortlægge den enkeltes forhold til virksomheden (dvs. både virksomhedens ønsker til den enkelte og den enkeltes til virksomheden) er i dag et centralt aspekt ved den mere individualiserede relation mellem virksomhed og medarbejder. Set fra virksomhedens side udgør de muligheden for på helt individuelt niveau at få et indtryk af den enkelte medarbejders situation, holdninger og ikke mindst ønsker til det fremtidige karriereforløb i virksomheden, samtidig med, at ledelsen kan kommunikere de ønsker, virksomheden har til den enkelte, og hvordan den enkelte kan bidrage til virksomhedens samlede målopnåelse, mere enkelt og direkte (Holt Larsen, 2010; Marsden, 2004; Rubery et al.., 2018).

Med andre ord udtrykker tilbud om MUS virksomhedens grad af investering i den enkelte medarbejder og i dennes udvikling. Set fra medarbejderens side udgør medarbejdersamtalen en mulighed for at fremsætte ønsker til egne muligheder i virksomheden, herunder ønsker om efteruddannelse, om at komme på deltid/fuld tid, om at få ændret sit jobindhold fx for at få mere ansvar osv. Disse ting kan de ofte være svært at få tid til i en travl hverdag, og det er derfor af stor betydning, både for den enkeltes velbefindende på arbejdspladsen og for mulighederne for at påvirke udviklingen af ens eget job, at denne mulighed er til stede. Medarbejdersamtaler har altid eksisteret for visse kategorier af medarbejdere (hyppigt for ledende 
og særligt betroede medarbejdere) og i visse brancher, men denne praksis har i dag bredt sig så meget, at selve forkortelsen MUS er blevet alment eje blandt beskæftigede. Deltagelse i medarbejdersamtale kan ses som en indikation på, hvor meget virksomheden vil investere i den enkelte medarbejder eller i gruppen af medarbejdere. Man kan også kritisere udbredelsen af MUS og henvise til, at denne samtale ikke foregår i et magtfrit rum, og at ledelsens krav om positivitet må føre til at kritikken "afmonteres" (Willig, 2013, s. 117-20), eller at MUS'en er et forum for udøvelse af blød magt ved at invitere til en samtale om succeser (Brinkmann, 2014, s. 45-6).

Denne kritik ændrer dog ikke ved, at MUS'en for medarbejderen er en mulighed for at lancere egne ønsker til ansættelsesforholdets udvikling og til mulighederne for imødekommelse af egne ønsker ud fra en noget-for-noget tankegang: Kræver virksomheden mere af mig, så kan jeg også fremsætte ønsker eller stille krav. Virksomheden kan jo altid sige nej til medarbejderens ønsker, men så kender medarbejderen også bedre sin situation. Man kan tilføje (jf. nedenfor), at MUS-samtaler bliver hyppigere, jo højere i virksomhedernes hierarki, man kommer, og at manglende tilbud om MUS derfor kan ses som et udtryk for manglende mulighed for individuel indflydelse på egen situation hos dem, der ikke sidder i ledelsespositioner. Ikke mange faglige organisationer - hvis overhovedet nogen - fraråder sine medlemmer at deltage i medarbejdersamtaler. Man skal altså ikke frygte MUS'en (!), men tværtimod vide, hvad man vil med den.

Kurser og efteruddannelse er nok nogle af de ting, man hyppigt taler om i MUS-samtaler. Det er derfor interessant at se på, at de manglende MUS-samtaler hænger sammen med manglende tilbud om netop fx kurser. Det kunne man jo forvente. Kurser og efter- uddannelse er centrale faktorer for dem, der gerne vil have et godt job, dvs. et udviklende job, et vellønnet job osv., og som gerne vil være bedre beskyttet (mindre undværlig) ved fyringsrunder og have lettere ved at få et nyt job, skulle det gå galt. Hvis atypisk ansatte halter efter her, risikerer de et mere permanent ophold på perronen, når kvalifikationstoget kører, så at sige. Derfor er ligelighed i tilbud om kurser og efteruddannelse en særdeles central faktor, når man skal bedømme atypisk ansattes reelle vilkår. En finsk undersøgelse har dokumenteret manglende muligheder for efteruddannelse netop for atypisk ansatte (Kauhanen \& Nätti, 2015, s. 789-91).

Endelig kan man rejse det spørgsmål, om de atypisk beskæftigede har samme muligheder for at udnytte deres tilegnede kvalifikationer. Dette tyder andre forskningsresultater kraftigt på, at de ikke har (Gundert \& Hohendanner, 2014; 2015). Begrundelsen kan være, at hvor normalbeskæftigede har muligheden for at påvirke eget jobindhold i retning af egen kompetence over tid, så foreligger denne mulighed ikke (eller kun i mindre grad) for atypisk ansatte. Dermed løber de atypiske en risiko for, at deres tilegnede oplæring eller uddannelse bliver "rusten", fordi den ikke bliver brugt. Nu er det klart, at man ikke anvender alt, man lærte i skolen og under sin erhvervsuddannelse, når man kommer ud i arbejdslivet, men graden af udnyttelse kan alligevel nemt variere. I en amerikansk undersøgelse tilkendegav 36\% af midlertidigt ansatte, at de var overkvalificeret til deres job imod $28 \%$ for fastansatte blandt 18-30-årige (Board of Governors, 2014, s. 22, jf. tillige Felstead et al., 2012, s. 4). Man kan tilsvarende for Danmark frygte, at atypisk beskæftigede i højere grad føler sig tvunget til at tage et job, hvor de ikke kan udnytte deres kvalifikationer, og altså er overkvalificerede. 
Spørgsmålene blev herefter formuleret som vist. Svarmulighederne står efter spørgsmålstegnet:

- Har du deltaget i en medarbejdersamtale (fx MUS eller lønsamtale) med din overordnede inden for det sidste års tid til halvandet? (ja/nej)

- Har du fået tilbudt kurser eller efteruddannelse i forbindelse med dit job? (ja/ nej)

- Hvordan vurderer du dine kvalifikationer i forhold til kravene i dit nuværende job? (føler sig overkvalificeret/føler der er et godt match/kvalifikationerne slår ikke altid til)

Svarene er oplyst i tabel 3. Det fremgår, at der er klare og signifikante forskelle til den negative side for de atypisk ansatte: Cirka to tredjedele af alle medarbejdere kommer til MUS i løbet af 1-11/2 år, men hvor dette gælder knap tre fjerdedel af de normalbeskæftigede, gælder det kun knap halvdelen af de atypisk ansatte (hhv. 72 og 48\%). Virksomhederne har således langt mindre fokus på integration af og muligheder for de atypisk ansatte.

\section{Tabel 3.}

Udvikling i jobbet: Mulighed for jobudvikling og anvendelse af kvalifikationer i jobbet, opdelt efter ansæattelsesform. Procent 2016.

\begin{tabular}{llllll} 
& Normalbeskæftiget & $\begin{array}{l}\text { Atypisk } \\
\text { ansat }\end{array}$ & Alle & Signifikans & N \\
\hline $\begin{array}{l}\text { Deltagelse i } \\
\text { medarbejder- } \\
\text { udviklings- } \\
\text { samtale }\end{array}$ & 72 & 48 & 65 & $* * *$ & \\
\hline $\begin{array}{l}\text { Tilbud om } \\
\text { kurser eller } \\
\text { efter- } \\
\text { uddannelse }\end{array}$ & 71 & 52 & 65 & $* * 302$ \\
\hline $\begin{array}{l}\text { Udnytter ikke } \\
\text { sine kvalifika- } \\
\text { tioner (føler sig } \\
\text { overkvalificeret) }\end{array}$ & 10 & 20 & 12 & $* * 303$ \\
\hline
\end{tabular}

Note: ${ }^{* *}: p<0,001$ ( $X^{2}$-test). $N$ angiver antal respondenter i procentgrundlaget.

Kilde: Undersøgelse af ansattelsesformer, september-oktober 2016.

Når det gælder tilbud om kurser og efteruddannelse er forskellen praktisk talt den samme. Dette var sådan set også forventeligt, da MUS og uddannelsestilbud vel ofte hænger sammen. Uddannelsestilbud er en investering fra virksomheden (her: det offentlige) i medarbejderen, og der investeres klart mindre i de atypisk ansatte.

Muligheden for at bruge sine jobrelevante evner og kvalifikationer er også af central 
betydning for ens karriere. Forskellen i andelen, der føler sig overkvalificeret, er her lidt mindre end i de to forrige spørgsmål, men det er alligevel slående at en femtedel af de atypisk ansatte angiver at deres kvalifikationer slet ikke udnyttes på en tilfredsstillende måde i deres job. (Man skal her bemærke, at datasættet ikke omfatter studerende, dvs. personer i studenterjob).

Samlet set er jobudviklingsmulighederne klart og signifikant mindre for atypisk ansatte.

\section{Vilkår B. Psykisk belastning - stress og manglende arbejdsliv/ familieliv-balance}

Der skrives meget om nedskæringer og øget arbejdsrelateret stress blandt offentligt ansatte herhjemme. I denne undersøgelse er der stillet to spørgsmål, der omhandler dette, og som forventet er der en betydelig andel af offentligt ansatte, der føler sig stresset, og som har vanskeligt ved at forene kravene i arbejds- og i familielivet. Imidlertid er spørgsmålet her om andelen er større blandt de atypisk ansatte. Forventningerne kan gå begge veje, idet fx deltid jo kan medføre, at man er mindre stresset og har lettere ved at tilgodese familielivet.

Spørgsmålene lyder som følger:

- Hvor ofte føler du dig stresset på dit arbejde? (Altid/ofte/af og til/sjældent/aldrig)

- Er det vanskeligt for dig at have en god balance mellem arbejds- og familieliv? (i høj/nogen/ringe grad/slet ikke)

I tabel 4 vises svarfordelingerne, og man kan for det første se, at en fjerdedel (24\%) af alle offentligt ansatte altid eller ofte føler sig stresset, mens næsten fire af ti i høj eller nogen grad har vanskeligt ved at forene arbejdslivets og familielivets krav (38\%). Det er betydelige andele, som på denne måde er under pres. Til gengæld er der ikke signifikante forskelle mellem de to ansættelsestyper. Atypisk ansatte er åbenbart hverken mere eller mindre stressede end de normalbeskæftigede.

Tabel 4.

Psykisk belastning: Følelse af stress og af manglende balance arbejdsliv/familieliv opdelt efter ansættelsesform. Procent 2016.

\begin{tabular}{llllll} 
& Normalbeskæftiget & $\begin{array}{l}\text { Atypisk } \\
\text { ansat }\end{array}$ & Alle & Signifikans & N \\
\hline $\begin{array}{l}\text { Føler sig altid } \\
\text { eller ofte stresset }\end{array}$ & 24 & 25 & 24 & - & 1.301 \\
\hline $\begin{array}{l}\text { Vanskeligt at } \\
\text { afbalancere } \\
\text { arbejdsliv og } \\
\text { familieliv (i høj/ } \\
\text { nogen grad) }\end{array}$ & 40 & 33 & 38 & - & 1.301 \\
\hline
\end{tabular}

Note: -: $p \geq 0,5$ ( $X^{2}$-test). $N$ angiver antal respondenter i procentgrundlaget.

Kilde: Undersøgelse af ansoettelsesformer, september-oktober 2016. 
Vilkår C. Juridiske rettigheder:

Ret til løn under sygdom m.m. og til den sjette ferieuge

En række former for social sikring og sociale rettigheder i arbejdsforholdet er betinget af en vis anciennitet, og der er dermed en klar risiko for, at de er mindre forekommende især blandt midlertidigt ansatte. Disse rettigheder udspringer primært af de kollektive overenskomster, men kan også være hjemlet i lovgivningen. Dette gælder bl.a. de følgende områder, som er belyst i denne undersøgelse, nemlig retten til løn under sygdom, retten til løn under barns sygdom, retten til løn under barsel samt retten til de fem feriefridage (de "særlige feriedage").

Hvor de normalbeskæftigede - især når de er overenskomstdækket - oftest har mulighed for at sikre sig disse vilkår, er der en klar risiko for, at disse rettigheder bliver overset eller "glemt", når det gælder de atypisk beskæftigede, selv om netop retten til et ansættelsesbevis næsten er mere vigtigt for fx den midlertidigt ansatte end for den fastansatte (forstået på den måde, at man ved en række af midlertidige ansættelser ved hvert stillingsskift har et klart behov for at kende de præcise vilkår for en ansættelse).

De næste spørgsmål omhandler tre aspekter under temaet løn under begrundet fravær, hhv. løn under sygdom, løn under børns sygdom og løn under barsel. Her drejer det sig klart om sociale rettigheder, hvor virksomheden bærer (en del af) risikoen i forbindelse med disse forhold. Disse rettigheder er forbundet med former for offentlig refusion til virksomheden (ved sygdom fx efter fire uger), men ved manglende rettigheder er den ansatte henvist til selv at gå til kommunen for at sikre sit indkomstgrundlag. Løn under begrundet fravær er en rettighed, der sikrer at virksomheden ikke tvinger medarbejderne til at skulle bede om sociale ydelser fra det offentlige. Funktionærrettigheder kan man have ved at være funktionær ifølge loven, eller ved gennem en kollektiv overenskomst at være sikret samme rettigheder. Dette gælder langtfra alle (om udbredelsen af funktionærstatus blandt lønmodtagerne i Danmark, jf. Scheuer, 2018).

En sidste lønmodtagerrettighed under dette punkt udgøres af det, der kaldes den sjette ferieuge, feriefridagene eller særlige feriedage. Når denne ekstra ferieuge har disse forskellige betegnelser, skyldes det behovet for at adskille dem fra de lovbestemte fem ferieuger. Det særlige ved den sjette ferieuge er nemlig, at den er overenskomsthjemlet. Kort fortalt er historien om den sjette ferieuge følgende:

Før 1998 havde man på nogle arbejdspladser historisk en tradition for, at en ekstra ferieuge var et særligt personalegode, og i en enkelt sektor (finanssektoren) har man været tidligere ude med at aftale sig til en ekstra ferieuge (benævnt omsorgsdage e.l.). Feriefridage som et mere generaliseret gode på det store arbejdsmarked opstod første gang i forbindelse med overenskomstfornyelsen på arbejdsmarkedet i 1998, hvor det forlig, der blev forkastet, allerede indeholdt én ekstra betalt fridag (juleaftensdag). I forbindelse med lovindgrebet efter ti dages Storkonflikt skete der to væsentlige ændringer, nemlig (1) der blev tillagt to børneomsorgsdage, og (2) alle disse ekstra fridage blev gjort valgfri eller lønombyttelige, et usædvanligt træk. Dette var hermed lovbestemt. I den fireårige overenskomst, der herefter blev indgået i 2000, blev antallet af feriefridage gradvis udvidet fra en til i alt fem, og de to børneomsorgsdage blev byttet ind (og forsvandt dermed) i denne forbindelse (Scheuer, 2004). Der blev ikke ændret på valgfrihedsprincippet, og ved overenskomstfornyelsen 2007 blev den skriftlige præsentation af valgfriheden gjort betydelig 
mere eksplicit, bl.a. i form af etableringen af en "valgfri lønkonto" på industriens og en række andre områder, dog ikke på alle (Scheuer, 2014).

Den ekstra ferieuge har således bevæget sig fra at være et særligt personalegode for visse grupper af medarbejdere i visse firmaer, til at være et mere demokratisk fordelt gode, som de fleste lønmodtagere har retten til, enten direkte pga. overenskomsten eller pga. overenskomsternes afsmittende effekt. En undersøgelse fra 2002 viste, at $75 \%$ af alle privatansatte på dette tidspunkt angav, at de havde ret til feriefridagene, og at kun en mindre del af disse (12\%) valgte at udnytte valgfriheden til at blive på arbejdet og hæve en ekstra uges løn i stedet (Scheuer, 2004). Man kan omvendt sige, at $25 \%$ af de privatansatte ikke havde ret til de særlige feriedage (i høj grad fordi de ikke var overenskomstdækket), og det interessante spørgsmål er derfor, om dette 'ikke at have de særlige feriedage' i særlig høj grad gælder for de atypisk ansatte medarbejdere. I 2010 havde 85\% af alle lønmodtagerne de særlige feriedage, men for atypisk ansatte, især midlertidigt ansatte, var andelen væsentligt lavere, 60\% eller mindre (Scheuer, 2011, s. 43).

Spørgsmålene i surveyen er de følgende:

- Har du ret til fuld løn under sygdom og ved tilskadekomst? (ja/nej)

- Har du ret til fuld løn under børns sygdom? (ja/nej)

- Har du ret til løn under barsel? (ja/nej)

- Har du ret den sjette ferieuge, de såkaldte feriefridage? (ja/nej)

Undersøgelsen viser generelt en høj dækning af disse rettigheder, som for funktionærer følger af funktionærlovens $§ 5$ og for ikke-funktionærer dækket af bestemmelserne i forskellige kollektive overenskomster, jf. tabel 5 .

Tabel 5.

Rettigheder: Ret til løn under sygdom, under barns sygdom og under barsel, samt ret

til den sjette ferieuge, opdelt efter ansættelsesform. Procent 2016.

Normalbeskæftiget $\begin{aligned} & \text { Atypisk } \\ & \text { ansat }\end{aligned} \quad$ Alle $\quad$ Signifikans N

\begin{tabular}{lccccc}
\hline $\begin{array}{l}\text { Løn under } \\
\text { sygdom }\end{array}$ & 94 & 75 & 89 & $* * *$ & 1.301 \\
\hline $\begin{array}{l}\text { Løn under } \\
\text { barns sygdom }\end{array}$ & 75 & 51 & 68 & $* * *$ & 1.301 \\
\hline $\begin{array}{l}\text { Løn under } \\
\text { barsel }\end{array}$ & 82 & 56 & 74 & $* * *$ & 1.301 \\
\hline $\begin{array}{l}\text { Har sjette } \\
\text { ferieuge }\end{array}$ & 95 & 72 & 88 & $* * *$ & 1.302 \\
\hline
\end{tabular}

Note: ${ }^{* *}: p<0,001$ ( $X^{2}$-test). $N$ angiver antal respondenter i procentgrundlaget.

Kilde: Undersøgelse af ansaettelsesformer, september-oktober 2016. 
Tabellen viser generelt en høj dækning af disse rettigheder, især løn under sygdom og den sjette ferieuge, men den viser også markante og signifikante forskelle mellem normalbeskæftigede og normal- og atypisk ansatte. Procentforskellene mellem de to grupper er på alle fire spørgsmål omkring 20 procentpoint eller derover: 94 versus $75 \%$ for løn under sygdom, 75 versus 51\% har løn under barns sygdom, 82 versus $56 \%$ har løn under barsel og endelig har 95 versus $72 \%$ ret til den sjette ferieuge. Risikoen (odds ratio) for ikke at have fx den sjette ferieuge er således syv gange større for de normalansatte end for de atypisk ansatte.

\section{Vilkår D. Økonomiske forhold: Forudsigelig økonomi og arbejdsmarkedspension}

I den nyeste internationale forskningslitteratur er der stærkt fokus på den grad af økonomisk usikkerhed, der gælder atypisk beskæftigede (Keller \& Seifert, 2013a, 2013b; Manyika et al., 2016; Standing, 2011). Det gælder både forekomsten af meget lave indkomster (noget som ikke belyses her) og forekomsten af svingende og uforudsigelige indkomstforhold, og manglende (mulighed for) arbejdsgiverfinansieret pensionsopsparing. I en finsk undersøgelse er der påvist betydelige forskelle mellem normalbeskæftigede og atypisk ansatte (Kauhanen \& Nätti, 2015, s. 793-4).

Dette belyses gennem de følgende temaer:

- Graden af indkomststabilitet

- Graden af økonomisk forudsigelighed
- Arbejdsmarkeds- eller firmapension med arbejdsgiverbidrag

- Subjektivt oplevet tilfredsstillende opsparing til pension

Indkomststabilitet og -forudsigelighed er nok ønsket af de fleste, da netop forudsigelighed muliggør planlægning på lidt længere sigt, hvilket vel især er vigtigt, hvis man har ansvaret (medansvaret) for andre (fx partner og børn). Stabiliteten kan ses på kort eller på lidt længere sigt, og indkomststabilitet på kort sigt er målt ved at spørge:

- Tjener du nogenlunde det samme hver måned, eller varierer det?

Hvis den månedlige indkomst er angivet som "nogenlunde det samme hver måned" betegnes indkomsten som stabil. I sammenhæng hermed er den subjektive følelse af forudsigelighed desuden målt ved at spørge:

- I hvilken grad vil du sige, at din økonomiske situation er forudsigelig og muliggør langsigtede beslutninger omkring familien ( $\mathrm{fx}$ beslutninger om køb af bolig, bil, sætte børn i verden osv.)?

Men hvad betyder da svingende månedlig indkomst? Gør det det vanskeligere at træffe mere langsigtede beslutninger omkring køb af bolig, bil, stiftelse af familie m.m.? Hvordan påvirkes den subjektive følelse af det forudsigelige i ens økonomiske situation? Det er tydeligt, at det spiller en rolle, jf. tabel 6 . 
Tabel 6.

Økonomiske forhold: Andel der har stabil indkomst, som finder økonomisk situation

forudsigelig, som har en arbejdsmarkedspension og som mener, de sparer tilstrækkeligt

op til pension, opdelt efter ansættelsesform. Procent 2016.

\begin{tabular}{|c|c|c|c|c|c|}
\hline & $\begin{array}{l}\text { Normal- } \\
\text { beskæftiget }\end{array}$ & $\begin{array}{l}\text { Atypisk } \\
\text { ansat }\end{array}$ & Alle & Signifikans & $\mathbf{N}$ \\
\hline $\begin{array}{l}\text { Andel der } \\
\text { tjener nogenlunde } \\
\text { det samme } \\
\text { hver måned }\end{array}$ & 83 & 65 & 78 & $* * *$ & 1.301 \\
\hline $\begin{array}{l}\text { Andel hvis } \\
ø \text { øonomiske } \\
\text { situation er } \\
\text { forudsigelig } \\
\text { og muliggør } \\
\text { langsigtede } \\
\text { beslutninger (i høj } \\
\text { og i nogen grad) }\end{array}$ & 81 & 61 & 76 & $* * *$ & 1.301 \\
\hline $\begin{array}{l}\text { Andel der har } \\
\text { arbejdsmarkeds- } \\
\text { pension }\end{array}$ & 89 & 67 & 82 & $* * *$ & 1.302 \\
\hline $\begin{array}{l}\text { Andel der mener, } \\
\text { at de sparer nok } \\
\text { op til at få en } \\
\text { økonomisk set } \\
\text { tilfredsstillende } \\
\text { pensionist- } \\
\text { tilværelse (i høj } \\
\text { og i nogen grad) }\end{array}$ & 66 & 44 & 59 & $* * *$ & 1.302 \\
\hline
\end{tabular}

Note: ${ }^{* *}: p<0,001$ ( $X^{2}$-test). $N$ angiver antal respondenter $i$ procentgrundlaget.

Kilde: Undersøgelse af ansaettelsesformer, september-oktober 2016.

Her kan det ses, at følelsen af manglende forudsigelighed faktisk er noget mere udbredt end selve indkomstvariationen: Blandt atypisk beskæftigede siger knap 61\%, at de føler, at deres økonomiske situation i høj eller i nogen grad er forudsigelig, imod $81 \%$ blandt normalbeskæftigede, som angiver at have stabil månedlig indkomst. For alle grupper af atypisk beskæftigede er det dog klart, at den manglende tilknytning til at fast job indebærer en følelse af mindre sikkerhed og forudsigelighed rent indkomstmæssigt.

Mens de to forudgående spørgsmål drejer sig om indkomststabilitet og forudsigelighed på kortere sigt, er spørgsmålet om den økonomiske situation på længere sigt belyst ved at spørge til pensionsopsparing. Der er dels spurgt til om man deltager i en firma- el- 
ler arbejdsmarkedspension (et forholdsvis objektivt spørgsmål), mens der desuden er spurgt til, om man føler, at man sparer tilstrækkeligt op til alderdommen, et mere subjektivt issue. Spørgsmålene lyder:

- Deltager du i en pensionsordning, enten via en arbejdsgiverbestemt ordning eller på grundlag af kollektiv overenskomst eller aftale?

- I hvilken grad mener du, at du sparer nok op til at få en økonomisk set tilfredsstillende pensionisttilværelse?

Svarene herpå kan også ses i tabel 6. Af denne tabel fremgår det, at der er betydelig forskel på forekomsten af arbejdsmarkedspension (AMP) mellem normalbeskæftigede og atypisk ansatte. Hvor knap ni af ti (89\%) af de normalbeskæftigede har AMP, gælder dette kun for to tredjedele (67\%) af de atypisk ansatte. Også denne forskel er klar og signifikant. Risikoen for at mangle AMP er faktisk tre gange så høj for atypisk ansatte.

Hvordan føles dette så rent subjektivt? Hvad føler lønmodtagerne, når det gælder deres egen pensionsopsparing, og er der her forskel mellem normalbeskæftigede og atypisk beskæftigede?

I tabel 6 er det første, man bemærker, omkring dette spørgsmål, at følelsen af at spare tilstrækkeligt op til tilværelsen som pensionist er noget mindre udbredt end den faktiske udbredelse af AMP: $82 \%$ af alle har AMP, mens kun 59\% føler, at de sparer tilstrækkeligt op. Mange lønmodtagere føler åbenbart, at AMP-ordningerne ikke sikrer dem tilstrækkeligt på langt sigt. Hvor to tredjedele (66\%) af de normalbeskæftigede føler, at de sparer tilstrækkeligt op, gælder dette kun for noget under halvdelen af de atypisk beskæftigede (44\%). Atypisk beskæftigelse er således en klar kilde til manglende AMP, men også til følelsen af manglende opsparing til alderdommen. Da AMP er et overens- komstanliggende, må det være et spørgsmål, om der er arbejdsgivere, der ikke overholder deres forpligtelser i forhold til atypisk ansatte, om de kollektive overenskomster holder nogen udenfor, fx pga. karensbestemmelser samt om de faglige organisationer er gode nok til at følge op på, om kolleger og medarbejdere $\mathrm{i}$ atypiske stillinger får deres rettigheder respekteret.

Sammenfattende kan man sige, at atypisk beskæftigelse er en klar risikofaktor når det gælder udsigterne for alderdommen, både den rent objektive deltagelse i en AMP med arbejdsgiverbidrag, og når det gælder den mere subjektive følelse af, at man sparer tilstrækkeligt op. Det er simpelthen sværere at sætte tilstrækkeligt af til pensionsopsparingen, hvis jobbet er deltid eller midlertidigt (dette fremhæves også i resultaterne fra en undersøgelse af atypisk ansættelse i USA og seks EU-lande, jf. Manyika et al., 2016, s. 90-91).

\section{Konklusion}

Den internationale forskningslitteratur har i de senere år påvist, hvordan den stigende udbredelse af atypiske ansættelsesvilkår har indebåret øget risiko for, at disse grupper af lønmodtagere reelt ikke oppebærer de rettigheder og vilkår, som ellers er blevet gældende for lønmodtagere i standardansættelsesforholdet, dvs. de normalbeskæftigede. I Danmark har omfanget af atypisk ansættelse kun været ganske lidt stigende, og det er derfor interessant at belyse, om og hvor meget forskel der er på rettigheder og vilkår herhjemme. Udenlandske studier har som oftest fokuseret på den private sektor, og de studier, der har inddraget det offentlige, ser gerne på enkelte brancher. Denne undersøgelse ser generelt på hele den offentlige sektor. Hvorvidt det kan dokumenteres, at atypisk ansatte også har større risiko for prekære vilkår i deres ansættelse i det offentlige, er 
det centrale spørgsmål i denne artikel. Eller sagt på en anden måde, at "non-standard employment is not necessarily precarious, but much of precarious employment is non-standard" (Keune \& Pedaci, 2019, s. 5).

I artiklen er fire aspekter af vilkår i arbejdet for atypisk ansatte i den offentlige sektor dokumenteret i en sammenligning med vilkårene for normalbeskæftigede, også i den offentlige sektor. Hensigten var at bedømme, hvorvidt de atypisk ansatte (ud over denne særlige status) lider afsavn eller en form for underskud i rettigheder, altså en yderligere prækaritet. Fire områder af vilkår er undersøgt: Muligheder for jobudvikling, psykisk belastning, juridiske rettigheder i ansættelsesforholdet samt økonomiske forhold.

Analysen viser, at på tre af de fire udvalgte områder var de negative forskelle (de manglende goder) for atypisk ansatte evidente. Mulighederne for jobudvikling, juridiske rettigheder i ansættelsesforholdet samt økonomiske forhold er klart ringere for atypisk

\section{REFERENCER}

Andersen, S. K. \& Karkov, R. (2011): Vikarer inden for og uden for den danske model. I T. P Larsen (Red.), Insidere og outsidere. Den danske models roekkevidde (s. 155-75). København: Jurist- og Økonomforbundets Forlag.

Board of Governors of the Federal Reserve System (2014). In the Shadow of the Great Recession: Experiences and Perspectives of Young Workers. Washington, DC. November 2014.

Brinkmann, S. (2014). Stå fast. Et opgør med tidens udviklingstrang. København: Gyldendal Business.

Crouch, C. (2015). Labour Market Governance and the Creation of Outsiders. British Journal of Industrial Relations, 53(1), 27-48. https:// doi.org/10.1111/bjir.12058.

DA (2014). Arbejdsmarkedsrapport. København: Dansk Arbejdsgiverforening. ansatte. Kun når det gælder psykisk belastning, kan der ikke ses signifikante forskelle, hverken positive eller negative.

Konklusionen bliver hermed, at prækaritetseffekter klart kan dokumenteres i den offentlige sektor herhjemme, og at det helt overordnede billede er, at der på en række centrale felter kunne ses en betydelig forskelsbehandling med hensyn til rettigheder og vilkår.

Da atypisk ansættelse omfatter mere end hver fjerde offentligt ansatte (29\%), omfatter de viste forskelle en meget stor gruppe af offentligt ansatte inden for alle mulige sektorer og faggrupper. Der er bestemt tale om ubegrundede uligheder eller ubegrundet forskelsbehandling i betydeligt omfang. Selv om Danmark således på mange områder har et bedre reguleret arbejdsmarked end i de øvrige europæiske lande, lider vores arbejdsmarked ikke desto mindre af de samme skavanker, når det gælder forholdene for atypisk ansatte.

Doeringer, P. B. \& Piore, M. J. (1971): Internal Labor Markets and Manpower Analysis. London: ME Sharpe.

Eichhorst, W. \& Tobsch, V. (2013). Has Atypical Work Become Typical in Germany? Bonn, IZA (Institute of Labor Economics) Discussion Paper 7609, September.

EP (2016). Precarious employment in Europe, Part 1: Patterns, trends, and policy strategy. Brussels: European Parliament, July.

Felstead, A., Gallie, D., Green, F. \& Inanc, H. (2012). Skills at Work in Britain. First Findings from the Skills and Employment Survey. London, Centre for Learning and Life Chances in Knowledge Economies and Societies, Institute of Education.

Finansministeriet (2017). Det danske pensionssystem nu og i fremtiden. København: Finansministeriet. 
Gallie, D. (2008). Task discretion and job quality. In D. Gallie (Ed.): Employment regimes and quality of work (pp. 105-136). Oxford: Oxford University Press,.

Gleerup, J., Nielsen, B. S., Olsén P. \& Warring, N. (2018): Prekarisering - og akademisk arbejde. Frederiksberg: Frydenlund Academic.

Gundert, S. \& Hohendanner, C. (2014). Do fixed-term and temporary agency workers feel socially excluded? Labour market integration and social well-being in Germany. Acta Sociologica, 57(2), 135-52. https://doi. org/10.1177/0001699313496588.

Gundert, S. \& Hohendanner, C. (2015).Active Labour Market Policies and Social Integration in Germany: Do 'One-Euro-Jobs' Improve Individuals' Sense of Social Integration? European Sociological Review, 31(6), 780-97. https://doi. org/10.1093/esr/jcv076.

Holt Larsen, H. (2010). Human Resource Management - Licence to Work. København: Forlaget Valmuen.

ILO (2016). Non-Standard Employment around the World. Understanding challenges, shaping prospects. Geneve: International Labor Organization. https://doi.org/10.1163/2210-7975_hrd4022-2016011.

Ilsøe, A. (2016). From living wage to living hours - the Nordic version of the working poor. Labour and Industry: a journal of the social and economic relations of work, 26(1), 40-57. https:// doi.org/10.1080/10301763.2016.1152534.

Kalleberg, A. L. (2009). Precarious work, insecure workers: Employment relations in transition. American Sociological Review, 74(1), 1-22. https://doi.org/10.1177/000312240907400101.

Kalleberg, A. L. (2011). Good Jobs, Bad Jobs. The Rise of Polarized and Precarious Employment Systems in the United States, 1970s-2000s. New York: Russell Sage Foundation.

Kauhanen, M. \& Nätti, J. (2015). Involuntary Temporary and Part-Time Work, Job Quality and Well-Being at Work. Social Indicators Research, 120, 783-799. https://doi.org/10.1007/ s11205-014-0617-7.

Keller, B. \& Seifert, H. (2013a). Atypische Beschätigung zwischen Prekarität und Normalität. Entwicklung, Strukturen und Bestimmungsgründe im
Überblick. Berlin, Edition Sigma: Hans Böckler Stiftung.

Keller, B. \& Seifert, H. (2013b). Atypical employment in Germany. Forms, development, patterns. Transfer. European Review of $\mathrm{La}$ bour and Research. 19(4), 457-74. https://doi. org/10.1177/1024258913501757.

Keune, M. (2013). Trade union responses to precarious work in seven European countries. International Journal of Labour Research, 5(1), 59-77.

Keune, M. \& Pedaci, M. (2019). Trade Union Strategies against Precarious Work: Common Trends and Sectoral Divergence in the EU. European Journal of Industrial Relations, electronic pre-publication. https://doi. org/10.1177/0959680119827182.

Larsen, T. P. (2011, red.). Insidere og outsidere. Den danske models roekkevidde. København:Juristog Økonomforbundets Forlag.

Larsen, T. P. \& Mailand, M. (2018). Lifting wages and conditions of atypical employees in Denmark - the role of social partners and sectoral social dialogue. Industrial Relations Journal, 49(2), 88-108. https://doi.org/10.1111/ irj.12205.

Larsen, T. P., Navrbjerg, S. E \& Johansen, M. M. (2010) Tillidsreproesentanten og arbejdspladsen. Rapport 1 fra Tillidsrepræsentantundersøgelsen 2010. København: LO, Landsorganisationen i Danmark.

Manyika, J., Lund, S., Bughin, J., Robinson, K., Mischke, J. \& Mahajan, D. (2016). Independent Work: Choice, Necessity and the Gig Economy. San Francisco, CA: McKinsey Global Institute Marsden, D. (2004). The 'Network Economy' and Models of the Employment Contract. British Journal of Industrial Relations, 42(4), 659-84. $\quad$ https://doi.org/10.1111/j.14678543.2004.00335.x.

Navrbjerg, S. E. \& Larsen, T. P. (2011). Tidsbegrænset ansatte og deltidsansatte - outsidere med rettigheder. I T. P. Larsen (Red.), Insidere og outsidere: Den danske models roekkevidde (s. 175-197). København: Djøf Forlag.

Pfeifer, C. (2011). Risk aversion and sorting into public sector employment. German Economic Review, 12(1), 85-99. 
Rubery, J., Grimshaw, D., Keizer, A. \& Johnson, M. (2018). Challenges and Contradictions in the 'Normalising' of Precarious Work. Work, Employment and Society, 32(2), 509-27. https:// doi.org/10.1177/0950017017751790.

Scheuer, S. (2004). Feriedage og valgfrihed Kan kollektive overenskomster og individuel valgfrihed forenes? Økonomi og Politik, 77(4), 5272.

Scheuer, S. (2011). Arbejde på risikovilkår - Fleksibilitet og manglende tryghed. LO-Dokumentation nr. 2 (s. 5-69). København: Landsorganisationen i Danmark.

Scheuer, S. (2014). Vilkår for kollektiv handling: Mellem institutionelle makrostrukturer og individuelle mikromotiver. I C. L. Ibsen \& L. Høgedahl (Red.), Økonomi og arbejde i det 21. århundrede: Et festskrift til Flemming Ibsen (s. 127-47). København: Jurist- og Økonomforbundet.

Scheuer, S. (2017). Atypisk beskoeftigelse i Danmark. Om deltidsansattes, midlertidigt ansattes og solo- selvstoendiges vilkår. LO-Dokumentation nr. 1. København: Landsorganisationen i Danmark. Scheuer, S. (2018).Funktionærloven, den faglige organisering og overenskomstdækningen. I A. J. Jacobsen \& L. Svenning Andersen: Funktionoerloven 80 år (s. 561-78). København, Juristog Økonomforbundets Forlag.

Standing, G. (2011). The Precariate. The New Dangerous Class. London: Bloomsbury.

Svalund, J. (2013). Labor Market Institutions, Mobility, and Dualization in the Nordic Countries. Nordic Journal of Working Life Studies, 3(1), 123-44.

Thörnquist, A. \& Engstrand, Å.-K. (2011). Precarious Employment in Perspective: Old and New Challenges to Working Conditions in Sweden. Series Work and Society, Volume 70. Brussels: P.I.E. Peter Lang Publishing Group.

Willig, R. (2013). Kritikkens U-vending. København: Hans Reitzels Forlag.

Steen Scheuer, professor emeritus, mag.art., ph.d., \& dr.merc., Syddansk Universitet e-mail: steen.scheuer@sdu.dk 